\title{
The Effectiveness of Cooperative Learning Strategy through English Village for Teaching Speaking Skill
}

\author{
Hengki \\ English Education Department, State University of Makassar, Jalan Bonto Langkasa, Makassar 90222, South Sulawesi, \\ Indonesia \\ Baso Jabu \\ English Education Department, State University of Makassar, Jalan Bonto Langkasa, Makassar 90222, South Sulawesi, \\ Indonesia \\ Kisman Salija \\ English Education Department, State University of Makassar, Jalan Bonto Langkasa, Makassar 90222, South Sulawesi, \\ Indonesia
}

\begin{abstract}
This study has five main purposes (1) to investigate the effectiveness of Cooperative Learning (CL) strategy through English Village (EC) for teaching speaking in communicative language function (2) to investigate the effectiveness of teaching speaking in transactional language function (3) to know the significance change on self confidence after being taught through English Village EV using CL strategy. (4) to know the significance change on self interest (5) to know the significance change on self regulation. The study was experimental by using one-group pretest-posttest design. The target population of this study was, in fact, is all students of English education department of private university or colleges in Indonesia. However, while the accessible population was only students of English department at the Islamic university of Kalimantan. The result of dependent $t$-test turned out to confirm that $C L$ strategy through $E V$ is effective to teach speaking skill for both, communicative and academic language function. The result of Wilcoxon test turn out to confirm that CL strategy through English is in significance change of the students' internal factors.
\end{abstract}

Index Terms - cooperative learning strategy, English village, communicative and academic language function of speaking

\section{INTRODUCTION}

\section{A. Language Functions}

According to Chamot and O'Malley (1994: 60), Language functions are identified for both social/communicative and academic purposes. In language functions, As we know that language is a tool for communication. Some opinions that said by linguists related to language functions. The first language functions refer to how individuals use language to accomplish specific tasks. The second, most commonly used language functions are those used to describe or give information or to express feelings (Bachman 1990). Cummins in O'malley and Pierce (1996:61) stats communicative language functions are those used to express meaning in a routine social context that is not cognitively demanding. Communicative language function includes greetings and leave-takings, requesting and giving information, requesting and giving assistance. Besides communicative language functions, Cummins in O'malley and Pierce (1996) also said that still any functions of language namely academic language functions that are critical for success in grade-level classroom. Academic language functions may be global in that they can be used across various contents areas or they may be content-specific particular to a single content area

This research attempts to show how important it is to teach learners to share knowledge and take advantage of their diverse abilities to improve their learning process, increase the students' speaking skill of the foreign language, and promote their social skills. This study illustrates an experience of English lecturer with Cooperative Learning (CL) strategy. It contains reflections on how this methodology could improve students' communicative and academic language function of speaking skill, and how the students taught with the CL strategy through English Village (EV) have better achievement in academic and communicative language function of speaking skill. The practical reason is that CL strategy is one of the effective strategies for the students in exchanging information between the learners. Kessler (1992: 8) states CL strategy is group learning activity organized so that learning is dependent on the socially structured exchange of information between learners in groups and in which each learner is held accountable for his or her own learning and is motivated to increase the learning of others. The idea is to make of the English classroom a 
place where, in addition to learning a foreign language, learners have the opportunity to share values and solve real problems of learning communicative and academic language function of speaking skill. The general problem statement posed by this experimental study is to know whether the students taught with CL strategy through EV have better speaking skill achievement than those taught not through CL strategy and EV.

This study, however, also focuses on one of the factors, namely teaching method as implemented in the teaching strategy. Learning strategies play a crucial role in second or foreign language acquisition. Learning strategies also help learners to gather new information and then assimilate those acquired information into their existing knowledge. In some universities of Kalimantan, specially, the implementation of cooperative teaching strategy is still monotonous. Some of the learners use conventional learning strategies. Slavin (1995) states that any relationship between strategy use and language proficiency, more proficient language learners use more learning strategies but less proficient language learners use less learning strategies. The results of study show that the successful language learners use more high level strategies than less successful learners. For More detailed discussion of language learning strategy, Griffiths (2003) proposed that learners with higher language proficiency expose themselves more frequently to the employment of language learning strategies. Based on these arguments, the possibility that the appropriate and effective strategy use might contribute to successful language learning is made accordingly and we cannot deny the positive relationship between speaking strategy use and successful learning.

Appropriate learning strategies help explains the performance of good language learners; similarly, inappropriate learning strategies would add the misunderstanding for the poor language learning. During the past decade, many researchers have focused on learning strategy use and effective language learning and the difference of reading strategy use between successful and less successful learners were highly discussed in various research studies.

Based on the strategies theory and the problems above, the writer ensures that CL strategies is one of the best vehicles for implementing a process oriented approach to teaching speaking skill. The writer intends to study it by investigating its effectiveness compared to the conventional strategy. The present study is intended to see the effectiveness of cooperative learning strategy over conventional one, not through Cooperative learning and EV, in teaching and learning of oral proficiency of speaking course. The effectiveness is to be measured in terms of achievement in speaking skill. In other words, it is to see whether the cooperative learning (CL) strategy through EV model leads to better achievement in speaking skill on the part of the students. Put in a question forms, the general problem to be answered through the present study is : Do the students taught with CL strategy through EV have better communicative and academic language function of speaking skill achievement on the post test than on the pretest .

\section{B. English Village as EFL}

English as a Second Language (ESL) and English as a Foreign Language (EFL) have been seen as rather distinct learning contexts. According to Richards and Schmidt (2010), ESL is frequently understood as referring to acquisition of English as an additional language in a setting where it is the dominant mode of communication, while EFL is envisioned as classroom study in a region where English does not play much of a role internally. EFL programs where in learners are exposed to a target language in small doses over a long period are sometimes referred to as drip feeding. While this is probably the most common experience of classroom foreign language learners, it has been found relatively ineffective in leading to functional fluency (Baker, 2011). Drip-feed EFL contexts have been associated with supposedly less-motivated learners. According to Gass and Selinker (2001) there also tends to be minimal access to English speakers, and therefore fewer learning opportunities. The view of the second/foreign continuum, according to prominence of a target language in a learners' community and the extent to which learning occurs in classrooms.

\section{METHOD}

\section{A. Research Design}

This study is intended for testing hypotheses about the effect of CL strategy through EV of teaching speaking skill toward improvement of students' speaking achievement in terms of general, academic language types and communicative language types of function. Ary et al. (2002: 280) state the term experimental design refers to the conceptual framework within which the experiment is conducted. The most important criterion is that design must be appropriate for testing the particular hypotheses of the study. In addition, Best (1981:68) defines experimental design is the blueprint of the procedures that enable the researcher to the test hypothesis by reaching valid conclusions about the relationships between independent and dependent variables.

The following table is an illustration of research design:

TABLE 1

RESEARCH DESIGN OF ONE GROUP PRETEST-POSTTEST DESIGN

\begin{tabular}{l|l|l|}
\hline Pre-test & independent variable & post-test \\
\hline Y1 & $\mathrm{X}$ & Y2 \\
\hline Where: \\
Y1: refers to observation in the pre-test \\
X: refers to the treatment \\
Y2: refers to the observation in the post-test
\end{tabular}


This study was intended for testing hypotheses about the effect of CL strategy through EV for teaching English speaking skill for both functions communicative and academic function. Of the explanation above, it denotes that design of the research is experimental. Experimental research is powerful research method to establish cause-and-effect relationship (Borg., Gall, 1989: 639) As stated in previous chapter, general hypothesis designed into two specifications that tested in the present study. The first specification of hypotheses says that the students who are taught with the CL strategy through EV have better communicative language function of speaking skill achievement. The hypothesis is stated such as, the students who are taught with the CL strategy through EV have better achievement in communicative language function of speaking skill on the post test than on the pre test. To put into null form. The hypothesis is stated such as, the students who are taught with the CL strategy through EV have no better achievement in communicative language function of speaking skill on the post test than on the pre test.

The research design employed in this study is one group, pretest-post test design. The number of the available subjects for the experiment of this study is 45. In addition, after the pretest is held so the subjects remained not to know which of the answers are correct and which are wrong. Finally, the length of the treatment, which lasted for four months, ensured that the subjects would not remember the items of the test. The evaluation is made on the basis of the lectures' observation of students' performance in speaking classes, participation in classroom activities, and speaking habits. The participants of the conference agreed to chance the position of the some subjects.

\section{B. Treatment}

As mentioned earlier, speaking teaching strategy through EV was studied in this research. In this case, teaching approach was cooperative language teaching CLT. Prior to the implementation of this teaching strategy through EV, the subjects were pretested to see their ability of communicative function of speaking.

\section{Population and Sample}

According to Ary et al. (2002:163) a population is defined as all members of any-well defined class of people, events or objects, the larger group about the generalization made is called a population. In this study, and the small group that is observed is called a sample. The target population is all the students of English department of private universities throughout in South Kalimantan who are at the third semester. This is under the assumption that they have many features in common. Some of the students never join UMPTN Test that conducted by state university. Most of them are inputs from SMA graduates so that they have same prior educational background and that they are relatively the same age. The populations of this study are students of the English Department of UNISKA Banjarmasin Indonesia who are programming speaking course in the third semester of the 2014/2015 academic year. The sample of this study is 45 students. Those students were assigned to the experimental group.

\section{Instruments and Technique of Collecting Data}

The study employed speaking test as the basic instrument for collecting data. The test was in interviews, speech, debate and role play format. The writer chooses those formats because they include task that involve relatively long stretches of interactive discourse. Discussing for solving problem, debating contest, role play and Interview were done to assess the students' speaking skill. Specially for interview test is to anticipate the leak of the questions, another students were not allowed to attend at the place where the interview taking place. Each student got the same questions.

\section{FINDINGS}

The results of the data analysis are presented in percentage of the students' result, and presented non parametric analysis for the students' internal factor self confidence, self-interest, and self-regulation. For the students' score in the pre test and the post test and for the increasing the students' internal factor used pre-questionnaire and post questionnaire. While the students' achievement in both communicative and academic functions of speaking using t-test analysis. The results of analysis are elaborated as follows:

Frequency of Students' Communicative Language Function of Speaking Indicator for students' ability Communicative Language Function of Speaking skill is based on pretest and posttest result.

TABLE 1

QUALIFICATION OF THE STUDENTS' COMMUNICATIVE LANGUAGE FUNCTION OF SPEAKING

\begin{tabular}{|c|c|c|c|c|c|}
\hline \multicolumn{3}{|c|}{ Pre-Test } & \multicolumn{3}{|c|}{ Post-Test } \\
\hline Score & Qualification & Students & Score & Qualification & Students \\
\hline$\geq 21$ & $\mathrm{~A}$ & 0 & $\geq 21$ & $\mathrm{~A}$ & 9 \\
\hline $16-20$ & $\mathrm{~B}$ & 5 & $16-20$ & $\mathrm{~B}$ & 36 \\
\hline $11-15$ & $\mathrm{C}$ & 30 & $11-15$ & $\mathrm{C}$ & 0 \\
\hline$\leq 10$ & $\mathrm{D}$ & 10 & $\leq 10$ & $\mathrm{D}$ & 0 \\
\hline
\end{tabular}

The table shows the frequency of students before teaching speaking skill using CLT strategy through EV. 0 student $(0.00 \%)$ got A qualification, 5 students (11.11\%) got B qualification, 30 students (66.67\%) got C qualification, 10 students $(22.22 \%)$ got D qualification. The frequency of the students after the teaching of speaking skill using CLT 
strategy through EV. 9 students (20.00\%) got A qualification. 36 students $(80.00 \%)$ got B qualification, no students $(0.00 \%)$ got $\mathrm{C}$ qualification and no students $(0.00 \%)$ got $\mathrm{D}$ qualification.

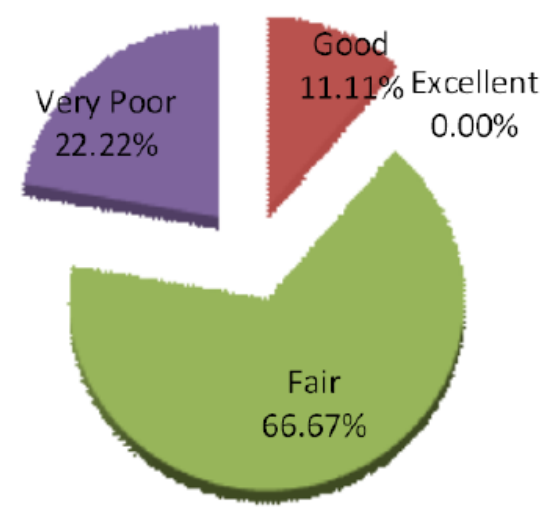

Figure 1 Percentage of the students' communicative language function of speaking before the teaching of speaking skill using CLT strategy through EV

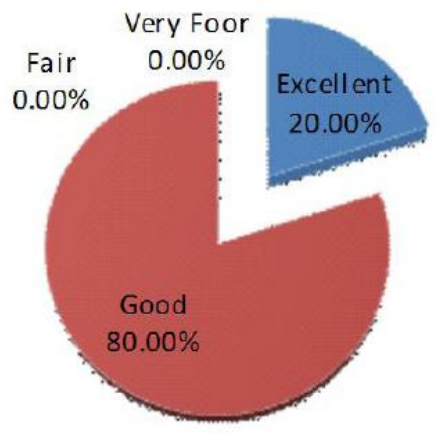

Figure 2 Percentage of the students' result on communicative language function after the teaching of speaking skill using CLT strategy through EV

TABLE 2

QUALIFICATION OF THE STUDENTS' ACADEMIC LANGUAGE FUNCTION OF SPEAKING

\begin{tabular}{|c|c|c|c|c|c|}
\hline \multicolumn{3}{|c|}{ Pre-Test } & \multicolumn{3}{|c|}{ Post-Test } \\
\hline Score & Qualification & Students & Score & Qualification & Students \\
\hline$\geq 21$ & $\mathrm{~A}$ & 0 & $\geq 21$ & $\mathrm{~A}$ & 6 \\
\hline $16-20$ & $\mathrm{~B}$ & 6 & $16-20$ & $\mathrm{~B}$ & 26 \\
\hline $11-15$ & $\mathrm{C}$ & 29 & $11-15$ & $\mathrm{C}$ & 11 \\
\hline$\leq 10$ & $\mathrm{D}$ & 10 & $\leq 10$ & $\mathrm{D}$ & 2 \\
\hline
\end{tabular}

The table shows the frequency of students before the teaching of speaking skill using CLT strategy through EV. 0 student $(0.00 \%)$ got A qualification, 6 students (11.11\%) got B qualification, 29 students $(64.65 \%)$ got C qualification, 10 students (22.22\%) got D qualification. The frequency of the students after the teaching of speaking skill using CLT strategy through EV. 6 students $(13.33 \%)$ got A qualification. 26 students $(57.78 \%)$ got B qualification, 11 students $(24.45 \%)$ and 2 students $(4.44 \%)$ got $\mathrm{C}$ qualification.

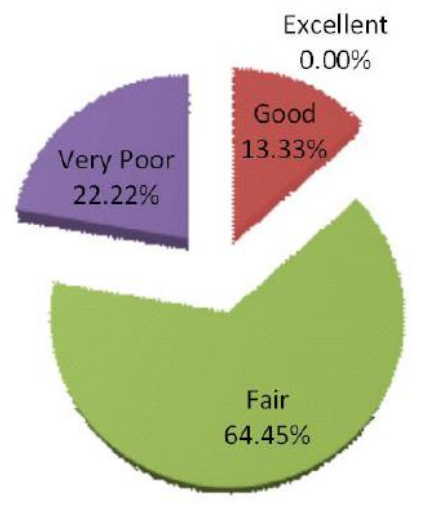

Figure 3 Percentage of the students' result on academic language function before the teaching of speaking skill using CLT strategy through EV 


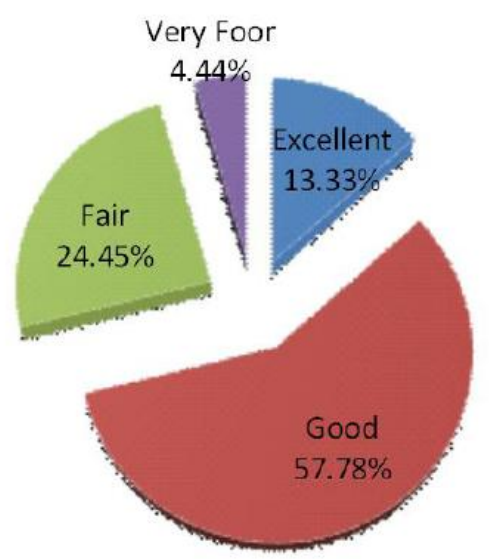

Figure 4 Percentage of the students' result on academic language function after the teaching of speaking skill using CL strategy through EV

Result of t-test for Students' Performance of Communicative and Academic Language Function of Speaking After doing two kinds of the test (pre test and post test) of communicative language function of speaking and computing the results that are summarized in table 4.3

TABLE. 3

SUMMARY OF COMPUTATION FOR T-TEST FOR COMMUNICATIVE AND ACADEMIC LANGUAGE FUNCTION OF SPEAKING
\begin{tabular}{|l|l|l|l|}
\hline Communicative & Academic & $=45$ \\
N & $=45$ & N & $=338$ \\
DD & $=306$ & $\sum \mathrm{D}$ & $=5.822$ \\
SD & $=6.800$ & $\mathrm{D}$ & $=2.102$ \\
\hline
\end{tabular}

The data shows that the average of the differences between the two means (D) of the students' score in communicative function of speaking is 6.800 while in academic function of speaking is 5.822 Next, the standard deviation of the differences (SD) of the students' scores in communicative function of speaking is 2.455 while in academic function of speaking is 2.102. Computation of the standard error of the mean for the differences (SXD) in communicative function of speaking is 0.365 while in academic function of speaking is 0.313 Finally, by dividing the average of the differences between the two means (D) and standard error of the mean for the differences, the t-value was obtained. In the present study the obtained t-value for the communicative function of speaking was 18.580 while the $t$-value for the academic function of speaking was 18.573 (see appendix on page 235). to the critical value of $t$ at $\mathrm{p}<00.1$ level significance of one-tailed test was 3.307 (d.f =44).

\section{Testing Hypothesis}

On the basis of the results obtained from the data analysis, the working hypotheses as stated in chapter 1 were formulated as presented in chapter III. In order that the testing hypotheses could be restated here. The null hypotheses were formulated as follows:

Students' score in communicative function of speaking who are taught with CL strategy through EV was not significantly higher on the post-test than on the pre-test.

Students' score in transactional function of speaking who are taught with the CL strategy who are taught through EV was not significantly higher on the post-test than on the pre-test.

\section{Testing Hypothesis for Communicative Function of Speaking}

The working hypothesis to be tested in this section states that the score of the students who are taught with CL through EV is higher on the post test than on the pre test. The t test analysis performed on the data of the students' score in communicative function of speaking comes to finding that t-value is 24.026 while the critical value of $t$ at $p<.001$ of one tailed test is 3.307 this indicates that the obtained t-value exceeds the critical t-value. Consequently, the null hypothesis stating that the students' score in communicative function of speaking who are taught with CL through EV is not significantly higher on the post test than on the pre-test is rejected. On the other hand, the working hypotheses stating that the students score in communicative function of speaking who are taught with CL through EV is significantly higher on the post-test than on the pre-test is accepted. This indicates that CL strategy through EV turns out to be more effective to the students' speaking ability in communicative function of speaking.

\section{Testing Hypothesis for Academic Function of Speaking}

The hypothesis for the students' score in academic function of speaking who are taught with CL strategy through EV is significantly higher on the post-test than on the pre-test. The computation using a t-test finds the obtained t-value is 22.784 while the required critical $t$-value is at $p<0.001$ of one-tailed is 3.307 this indicates that the obtained $t$-value exceeds the critical t-value. As the result, the null hypotheses stating that the students' score in academic language function of speaking who are taught with the CL trough EV is not significantly higher on the posttest than on the pre- 
test is rejected. Conversely, the alternative hypothesis is accepted. This indicates that CL through EV of teaching speaking turns out to be more effective to improve the students' ability in academic function of speaking.

\section{DISCUSSION}

In a finding, it shows the Effectiveness of CL strategy Through English Village of Teaching Speaking in communicative language function. The application of CL Strategy through EV brings about positive effect to the students' speaking ability in communicative function of speaking. That is students who are taught with CL strategy through EV get better score in communicative function of speaking on the post test than on their pre test. As a result, the null hypothesis is rejected, while the working hypothesis is accepted. It denotes that the present study proves that CL strategy more effectively to be applied through EV to increase students' speaking ability in communicative function of speaking.

In this study, it can relate to Yang' point of view (2005) states that the use of CL techniques can lead to positive attitudes towards CL and increased speaking skills. It must be admitted that students who interact and speak achieve better in oral skills in most cases than those who always keep silent. It is urgent that English speaking ability is one of the most important skills to be developed and enhanced in language learners, particularly in an academic and communicative setting.

For academic function of speaking analysis succeeds in proving that the students who are taught with CL strategy through EV have significantly better score in academic function of speaking on the post test than on their pre test. Therefore, the null hypothesis is rejected, whereas the working hypothesis is accepted. This indicates that CL strategy turns to be more effective to develop students' speaking ability in academic function of speaking through EV.

Related to this academic language function. Townsend at al. (2012: 92) states academic language function is a specialized language both oral and written, of academic settings that facilitates communication and thinking about disciplinary content. In addition, they explained that academic language is a functional tool that allows for discussion and reflection on the types of complex ideas and phenomenon that comprise the middle grade curricula.

Using CL strategy through EV succeed and more efficient and effective to improve the students' speaking skill in academic language function. The students' oral communication after joining the program is much better than before. This study agrees with exiting theories of how languages are learnt. The theories states that there are some factors affecting second language learning, they are intelligence, aptitude, personality, motivation, learners preferences, learners beliefs, age of acquisition, and environment. Of the all factors, there are two factors who have given great contribution to the students' speaking achievement in both functions of this study, they are students' motivation and environment.

The use of good strategy in improving the learners' speaking skill may accelerate the students' speaking competence whether the communicative abilities or academic ability. Slavin (1995) states that any relationship between strategy use and language proficiency. more proficient language learners use more learning strategies but less proficient language learners use less learning strategies. In addition, Bruen (2001) assumed that a high level of strategy use was related to high language proficiency and successful learners' use more learning strategies.

This study is most significant in that it has moved studies on CL a step further. The findings of this study have demonstrated the effectiveness of CL strategy through EV in the teaching and learning of speaking skill for the English department students. It is also significant in that it demonstrated the effects of teaching and learning that using CL strategy through EV to increase the students' self interest, self confidence and self regulation.

\section{CONCLUSION}

From the results of the data analyses as reported in Chapter IV and discussed in chapter V, the following conclusions are then made. Using CL strategy in teaching speaking skill through EV and no using CL strategy have different impact on students' speaking skill achievement. In this case, students who are taught speaking skill using CL strategy through EV tend to have better speaking skill achievement after being taught than before. In other words, the former strategy facilitates learning more than latter.

As far as the communicative function of speaking skill is concerned, by using CL strategy through EV, it is able to assure that the result must be more effective, the students tend to have better performance on communicative language function of speaking. It is proven from the data that shows the higher students' speaking skill performance on the post test than on the pretest. This indicates that the students who are taught speaking skill with CL strategy through EV have better score after being taught or after joining the program.

Using CL strategy through EV for the teaching of speaking skill is more effective. It is proven from the data that shows the higher students' speaking skill achievement on the post test than on the pretest. This indicates that the students who are taught speaking skill with CL strategy through EV have better score after being taught than before.

In short, the use of the CL strategy for the teaching of speaking skill in academic language function through $\mathrm{EV}$ is in general more effective after being taught than before. However, when viewed from the types of language function, the communicative language function of speaking skill is much more effective. 


\section{REFERENCES}

[1] Ary, Donald, Jacobs, L. C. (2002). Introduction to Research in Education. Group Wadsworth.

[2] Allyn and Bacon Scrivener, T. (1994). Learning Teaching: A Guidebook for Language Teachers. MacMillan: Heinemann.

[3] Bachman, L. F. (1990). Fundamental Considerations in Language Testing. Oxford: Oxford University Press.

[4] Borg, W.R., Gall, M.D. (2007). Educational Research: An Introduction, University of Oregon press.

[5] Bruen, J. (2001). Strategies for success: Profiling the effective learner of German. Foreign Language Annals.

[6] Chamot, A. U. \& Kupper, L. (1989). Learning Strategies In foreign Language Instruction. Foreign Language Annals, 22(1), p. 13-34.

[7] Cummins, J. (1984). Bilingual Education and Special Education: Issues in Assessment and Pedagogy. San Diego: College Hill

[8] Chamot, A. U., \& O'Malley, J. M. (1994). The CALLA handbook: Implementing the cognitive academic language learning Approach. Reading, MA: Addison-Wesley.

[9] O’Malley, J. M., \& Pierce, L. V. (1996). Authentic Assessment for English Language Learners: Practical Approaches for Teachers. U.S.: Addison-Wesley.

[10] Gass, S. \& Selinker, L. (2001). Second Language Acquisition: An Introductory Course. Mahwah,! NJ: Lawrence Erlbaum.

[11] Griffiths, C., (2003). Patterns of language learning strategy use. System, DO Press.

[12] Holliday, D. C. (2002). Using cooperative learning to improve the academic achievements of inner-city middle school students. Presented at the annual meeting of the American educational research association national conference. New orlean.

[13] Krashen DS (1982). "Principles and Practice in Second Language Acquisition". New York: Pergamum Publish.

[14] Kessler, C. (1992). Cooperative Language Learning. Englewood Cliffs, New York: Prentice Hall.

[15] Kagan. (1995). We can talk: CL in the elementary ESL classroom. Washington, DC: ERIC Clearinghouse on Languages and Linguistics.

[16] Lie, A. (2000). CL: Changing Paradigms of college teaching. Petra Christian University Surabaya, Indonesia, p. 121-131.

[17] Larsen-Freeman, D. (1986). Techniques and Principles in Language Teaching. New York: Oxford University

[18] Richards, J. C. and Schmidt, R. (Eds.) (1983). Language and communication. Harlow, Essex: Longman.

[19] Slavin, R.E. (1995). Cooperative Learning: Theory, Research and Practice (2nd Ed). London.

[20] Townsend, D., Filippini, A., Collins, P., \& Biancarosa, G. (2012). Evidence for the Importance of academic word knowledge for the academic achievement of diverse middle school students. The Elementary School Journal, Vol. 112, No. 3, Academic Language (March 2012), p. 497-518 Published by: The University of Chicago Press: Retrieved 12 retrieve 12 September 2014 http://www.jstor.org/stable/10.1086/663301.

[21] Yang, A. and Cheung, C. (2005). Activities for communicative teaching and cooperative learning office of English language programs (Hong Kong). English Teaching Forum, Volume 41, Issue 3.

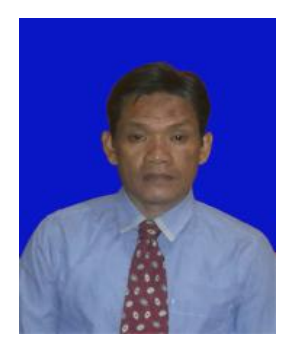

Hengki was born in Pinrang, Indonesia, on December 31, 1969. He finished his S.S. in English Letters department of Indonesia Moslem University at Makassar in 1995. He earned his English Education, M.Pd in Makassar State University in 2002, He is as a lecturer of KOPERTIS IX in Indonesia and being employed at Kalimantan Islamic University since 2005. His position is a head of language laboratory.

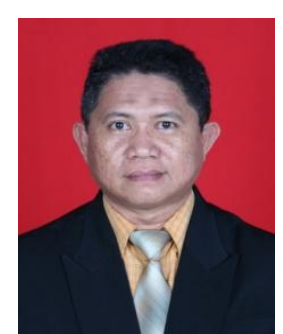

Baso Jabu was born in Pangkep, Indonesia, on May 13, 1964. He finished his B.A. in English education at Institute for Teacher Training at Makassar, Indonesia in 1987. He earned his M.A. and Ph.D. in English teaching and testing at Hasanuddin University at Makassar, Indonesia in1995 and 2007 respectively.

He is a PROFESSOR at the State University of Makassar, Indonesia. He is also currently the Director of Language Center at the university and an assessor of Teacher and Lecturer Certification. He was an education specialist consultant of USAID projects in Indonesia. His publications are: English Language Testing, Makassar: UNM Publisher, 2008 and Introduction to Business English, Makassar: UNM Publisher, 2009. His previous and current research interests are English teaching and testing.

Prof. Jabu has been a member of TEFLIN (Teaching English as a Foreign Language in Indonesia) since 2007 and MLI (Indonesia Linguistic Society) since 2005. Prof. Jabu is a member of editor of Performance: An English Teaching Journal and EFL International.

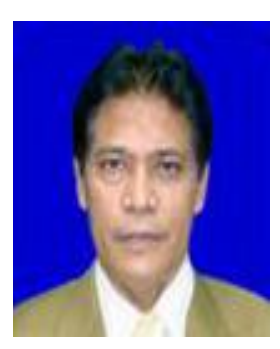

Kisman Salija, M. Pd. is a senior lecturer at the English Department. He has been teaching English at UNM since 1980. He is now teaching Academic and Creative Writing Courses at undergraduate and graduate level at English Department UNM., Indonesia. His research interests are on the Teaching of Academic and Creative Writing by Indonesian young Learners English, and Language Testing. 